\title{
El papel de los mawāli en los desarrollos políticos de Kufa: Un análisis histórico-social
}

\author{
The role of the mawāli in the political developments of Kufa: \\ A historical-social analysis \\ Reza Gahremani ${ }^{1}$, Ja'far Hassanzadeh Kalshani ${ }^{2 a}$, Mahboub Mahdavian ${ }^{3}$ \\ Department of History of Islamic Nations, Khoy Branch, Islamic Azad University, Khoy, Iran ${ }^{123}$ \\ iD Orcid ID: https://orcid.org/0000-0002-1703-01801 \\ (iD) Orcid ID: https://orcid.org/0000-0002-9968-52352 \\ (iD) Orcid ID: https://orcid.org/0000-0002-5887-16803
}

Recibido: 12 de abril de 2010

Aceptado: 15 de enero de 2021

\begin{abstract}
Resumen
El objetivo de esta investigación fue analizar el papel de los mawāli en los desarrollos políticos en Kufa (Iraq). Este artículo busca explicar el papel de la población mawāli en las interacciones y desarrollos políticos y sociales de Kufa, refiriéndose a recursos confiables y examinando las palabras de historiadores. El método de esta investigación fue descriptivo-analítico el cual se realizó en un método documental utilizando las fuentes disponibles. Los resultados mostraron que debido a su estructura social compleja y heterogénea, esta ciudad albergaba varios estratos sociales que jugaron un papel clave en el desarrollo político, incluido el mawāli. En el principio y la teoría del Islam, la igualdad y la hermandad de los musulmanes son importantes. Pero este no fue el caso en la práctica y los mawāli fueron expuestos al insulto, el desprecio y los prejuicios de los árabes. Los mawāli eran considerados esclavos y ciudadanos de segunda clase por los árabes porque, a diferencia de los árabes guerreros, cultivaban o trabajaban como jornaleros, artesanos, tenderos y comerciantes y trataban de liberarlos de la esclavitud. Gradualmente, el mawāli ganó un papel y un lugar relativamente importantes y altos puestos en los pilares administrativos y militares, de modo que muchos comandantes famosos y los primeros eruditos islámicos eran principalmente de mawāli. Esta gente tuvo una gran influencia cultural en los árabes.
\end{abstract}

Palabras clave: Kufa, Mawāli, Umayyad, Política, Islam, Irán

\footnotetext{
Abstract

The objective of this research was to analyze the role of mawāli in the political developments in Kufa (Iraq). This article seeks to explain the role of the mawāli people in the interactions and

${ }^{a}$ Corresponding Author E-mail: hasanzadeh.jafar@gmail.com
} 
political and social developments of Kufa by referring to reliable resources and examining the words of historians. The method of this research was descriptive-analytical which was done in a documental method using the available sources. The results showed that due to its complex and heterogeneous social structure, this city hosted various social strata that played a key role in political developments, including the mawāli. In the principle and theory of Islam, equality and brotherhood of Muslims are important. But this was not the case in practice and the mawāli were exposed to insult, contempt and prejudices of the Arabs. The mawāli were considered as slaves and second-class citizens by the Arabs because unlike the warlike Arabs, they farmed or worked as laborers, craftsmen, shopkeepers and merchants and tried to free them from slavery. Gradually, the mawāli gained a relatively important role and place and high positions in the administrative and military pillars so that many famous commanders and early Islamic scholars were mainly from the mawāli. These people made a great cultural influence on the Arabs.

Keywords: Kufa, Mawāli, Umayyad, Politics, Islam, Iran

\section{Introduction}

By looking at the history of political, social and cultural developments of cities in different periods, one can understand the role of cities in the transfer of culture, beliefs and religion from one land or geographical area to another. At some point in history, governments, in addition to political functions, have intentionally or unintentionally used these cities as a means of transmitting their own culture to other lands (Dinouri, 1991: 288). The city of Kufa as the inheritor of the geographical location of Hira, in addition to its military function which was a key factor in its establishment, acquired the same characteristic over time due to being located on the border of two cultures (Majlesi, 2009). After the defeat of the Sassanid Empire, the Muslims needed a military base outside the Arabian Peninsula to command their attacks, conquer new lands, spread Islam and also manage their possessions. Subsequently, the military city of Kufa was established, and with regard to the importance of the conquests to the Muslims, this city became one of the important areas of the Islamic Caliphate (Momtahen, 2006).

Kufa was built in 17 Hijri lunars (It is related to the Islamic year. Equivalent to the Gregorian years) and in fact during the time of the second caliph by Sa'd ibn Abi Waqqas, after returning from the battle of Qadisiyyah. This city emerged as a military base consisting of numerous Arab tribes and mawāli. An important issue after the formation of Kufa was the presence of different Arab tribes, which created a heterogeneous tribal structure and composition and each area belonged to a specific tribe and with the expansion of Islamic borders and the need to have more troops and soldiers, the population of Kufa increased. A number of Iranians who had the 
opportunity to develop and attend other social classes with the fall of the Sassanid Empire went to different cities to find new jobs, among which Kufa was a suitable place for them. This article is intended to investigate the role of mawāli according to their role in the political developments of Kufa (Majlesi, 2009).

\section{Methodology}

The researcher uses the method of historical research when dealing with an issue that has occurred in the past and ended in the past. In other words, the time frame is closed. Centuries ago, it happened (Kheiri, 1983). Historical research is a systematic and accurate study of the past, and the historian works with great skill on points about an event or a person (Pishvaei, 2002). Historical research is the application of the scientific method to historical issues. This research is in fact a systematic search. In other documents and sources, which contain facts in the field related to the historical researcher's question about the past. Therefore, historical research necessarily deals with events that have taken place before the researcher's decision to study them (Dinouri, 1991). In this study, researchers seek to examine the role of mawāli in the political developments of Kufa in order to answer the questions that have been questioned and resolve the existing ambiguities.

\section{Historical Review of the Mawali People in Kufa}

\section{Mawāli}

Mawāli, who's singular is mawla, has several meanings in Arabic, one of which is servant. On the other hand, in some historical and literary books, all non-Arab nations that came under Arab domination were called mawāli (Dinouri, 1991). Further, among the Arabs, whenever the master freed his servant, the relationship between the two after freedom was called wala (friendship) and the freed servant was called mawla. For example, Zayd ibn Harithah was called the mawla of the Prophet because Muhammad had set him free. With the development of Islam, due to the increase in freed slaves of the Arabs, a new social class emerged under the name of mawāli (Majlesi, 2009).

Their first major entry into the Islamic field was in the form of an army of four thousand men. After the defeat of Rostam Farrokhzad, the commander of the Iranian army, against the Muslims and his death, they decided to convert to Islam. To this end, they entered into negotiations with Sa'd ibn Abi Waqqas, the commander of the Muslims. They were known at that time as the emperor's soldiers and gave their leadership to a person named 'Deylam'. After entering the Islamic field, they made a pact with a tribe of Bani Tamim led by 'Zohra 
ibn Hawiyah' and thus became known as 'Mawāli Bani Tamim'. After fighting in the battles of Mada' in and Jalula, they came to Kufa and settled in an area of it. From this time on, they were influential in various political and even ideological developments in Kufa (Balazori, 1987, p. 279).

This group, known as "Hamra" (red-faced) by the Arabs because of the freshness of their skin and cheeks and also due to the name of their leader, was referred to as "Hamra Deylam". In Kufa, they formed the primary nucleus of the mawāli and over time, their population increased by the migration of other Iranians so that during the rule of Imam Ali (AS) in Kufa, they constituted about one fifth of the population of Kufa. At this time, they had a famous mosque in Kufa, which was known as "Hamra Mosque” (Majlesi, 2009).

\section{Class}

The word "class" means a group of people, which is called Classe in French, derived from the Latin root "Classis". The concept of class was first introduced in the $19^{\text {th }}$ century by Adam Smith, but there is disagreement over the definition of social class (Vosouqi et al., 1991). Below are some definitions in brief:

1- Arthur Boer (1902) believed that social class is a set of social groups that enjoy similar economic conditions and relations of production, social status and political stance (Vosouqi et al., 1991).

2- McIver and Parsons (1913) believed that social class is a group or groups of people who are distinguished from other classes on the basis of social status and their level of education, source of income, housing, place of residence, etc (Vosouqi et al., 1991).

3- Sorokin (1905) also considers social class as a group of people who have similar conditions in terms of job and economic and political status (Vosouqi et al., 1991).

4- Orberg (1916) believes that social class is a large group of people with similar conditions in terms of status in a given social system of production based on historical conditions in relations of production and social relations of production and access to means of production and how to achieve social wealth (Vosouqi et al., 1991).

The general definition of social class is as follows: A part of society that differs from other parts of society in terms of common values, a certain social status, collective activities, the amount of wealth and other personal assets and social customs (Vosouqi et al., 1991). 


\section{Historical geography of Kufa and the reasons for its establishment}

Kufa is located eight kilometers east of Najaf on the banks of the Euphrates River. This city is bounded by the Euphrates to the east, a desert to the west, the ancient city of Hira to the southwest and Dhu al-Kifl to the northeast. It is located near the Euphrates and one of the branches of the Euphrates is flowing in its east (Istakhri, 1989).

After the victory of the Muslims in the battle of Qadisiyyah and the siege of Ctesiphon (Le Strange, 2004), the second caliph ordered Sa'd ibn Abi Waqqas, the commander of the Islamic army in Iraq, to stay there. After living in Mada'in for fourteen months, the Muslims could not get used to it, despite the privileges of this city. Due to the herds they brought with them from the Arabian Peninsula, they had to adapt to a place that had both a dry and desert environment and a suitable agricultural situation. In fact, Muslim commanders in Mesopotamia were looking for a suitable place to protect the newly occupied regions, without being separated from Saudi territory by natural obstacles, such as rivers and the sea. After correspondence with the second caliph and on his order, Sa'd ibn Abi Waqqas sought a place suitable for the living of the Arabs and their camels (Tabari, 1993). So, the purpose of building Kufa was to "establish a permanent camp for the army on the western side of the Euphrates" (Le Strange, 2004).

For the other hand, the city of Kufa was considered a political-military base in Mesopotamia during the Umayyad period and was regarded a center for controlling and monitoring Iran due to its geographical location. Indeed, in the Umayyad era, the ruler of Iraq was the main ruler of Iran as far as Khorasan and this increased the political-military importance and, as a result, the economic prosperity of Kufa during the Umayyad reign (Izadi, 2000). 


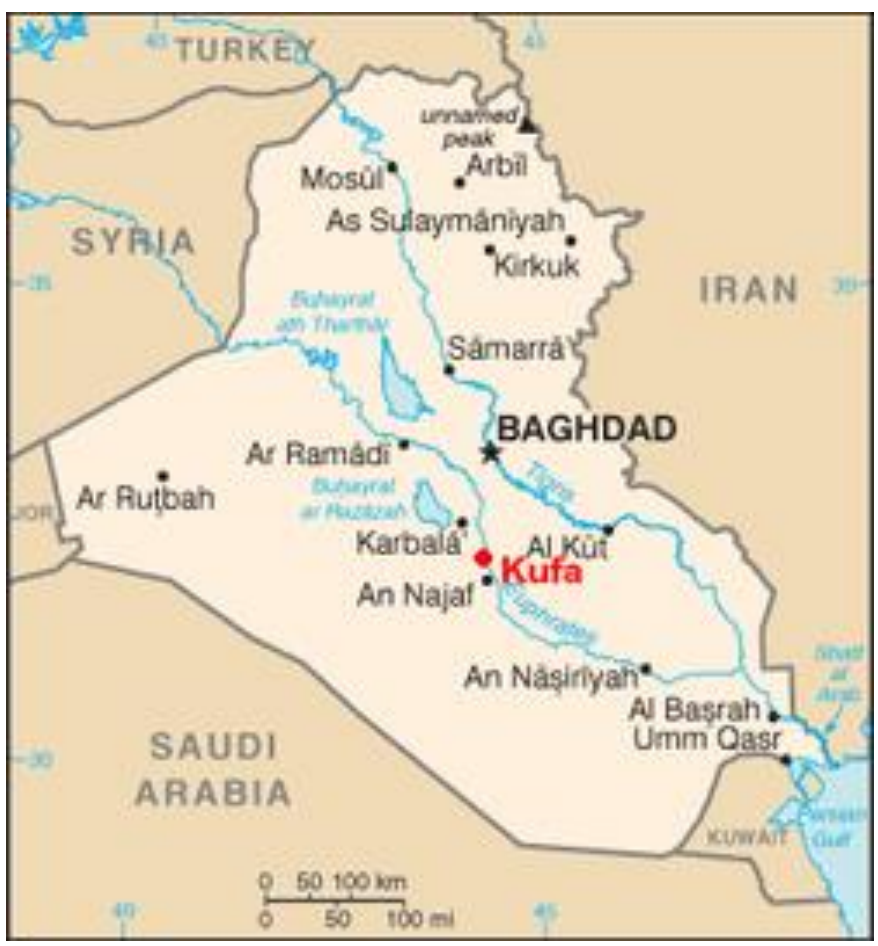

Figure 1. Location of Kufa in Iraq

\section{The socio-political situation of Iranians in Kufa}

\section{Iranians and Islam}

Since the formation of Kufa coincides with the invasions of the soldiers of the Islamic Caliphate to the borders of Iran and the entry of Islam into this land, it seems that some points should be mentioned in this regard. The history of Iranians' acquaintance with Islam dates back to the time of the life of the Great Prophet. Salman, one of the most prominent companions of the Prophet (PBUH), was Iranian. The Yemeni Persians also welcomed Islam with open arms and remained steadfast in their Islam after the decease of the Prophet (PBUH) although most of the Yemeni Arabs apostatized. The Iranian ruler of this land called Si Bakht sent a cash tax to Medina instead of Ctesiphon (Balazori, 1987). In fact, a large number of people living under the Sassanid rule were burdened by heavy taxes and numerous wars and did not make a considerable effort to maintain this rule. This made useless even the sacrifice of some Sassanid generals such as Rostam Farrokhzad, Bahman Jaduya and Hormozan (Dinouri, 1991).

However, with respect to the acceptance of the rights of the People of the Book, including Zoroastrians, and their freedom of action in maintaining their beliefs, the full spread of Islam in Iran took centuries. But from the very first days of the arrival of Muslims, there is ample evidence 
concerning the cooperation and assistance of Iranians and even their acceptance of Islam (Balazori, 1987).

\section{Truth and truth-seeking}

Islam is a religion that did not limit itself to a particular nation, but addressed the nature of all human beings. That is why God says: "So direct your face toward the religion, inclining to truth. [Adhere to] the nature of Allah upon which He has created [all] people. No change should there be in the Divine creation. That is the correct religion, but most people do not know" (The Holy Quran, Surah Ar-Rum, Verse 30).

Although the Prophetic tradition and the manners of Ahlul-Bayt emphasized this point, the Umayyad and Abbasid caliphs soon took a different path and the pre-Islamic Arab aristocracy and the tyrannical aristocrats spoke of the preference of one race over another. The humiliation of nonArabs was pursued while several verses in the Quran emphasized the issue of "the position of man as the caliph of God on earth and even as having dignity" (The Holy Quran, Surah al-Baqarah, Verse 29).

Finally, what Islam proposed was the establishment of truth in human society because truth has an inherent existence. Therefore, truth is durable and lasting, but falsehood has a subordinate and non-original existence although it appears under the guise of truth. This idea was at odds with the ignorant Arab thought as well as the distorted Zoroastrianism at the time. According to John Noss, the belief in the origin of evil and the cause of crime and offence has evolved over time and gradually turned Zoroastrianism into a moral dualism (Noss, 1991).

\section{The place of the Mawāli people in Kufa}

Mawāli is the plural of mawla and literally means friend, helper, great owner, blesser and liberator, lord, master, lover, chief, freemen and so on (Dehkhoda, 1998). The term 'wala' (friendship) also comes from the root 'mawla' meaning lord and master (Momtahen, 2006). Mawla and mawāli have been used in the Quran in two meanings: teacher and educator and honorable and respectable (Dehkhoda, 1998). Mawāli, in terms of Islamic history, also includes non-Arab natives who allied themselves with the Arabs through neighboring treaties and non-Arab Muslims who did not take part in the war against the Muslims and were not captured (Zubaydi, 1970). The Iranians, who were captured by the Arabs in groups during the wars, or even those who later converted to Islam and were liberated were also considered among the mawāli. Besides, "those 
who gradually abandoned the religion of their fathers and converted to Islam were among the mawāli. This group entered the Islamic regions from outside the Islamic territory from the beginning of the first century $\mathrm{AH}$ and with their own specific goals, which were sometimes benevolent, they chose the love of Ahlul-Bayt (AS) and mixed their heart teachings with this love and changed their basic structure and played the greatest role in its development and expansion, especially in the first century (Momtahen, 2006).

Mawāli were called non-Arabs who became part of the Arab tribes by entering the Islamic territory and making alliances with Arab tribes so that those Arab tribes added their name to the name of their tribe when introducing. For example, each of the mawāli of Bani Tamim tribe was referred to as Mawla Bani Tamim and the most important benefit that mawāli gained from this situation was that when committing a crime and being sentenced to blood money, the members of the tribe rushed to their aid as they fought in wars with their allied tribe" (Zubaydi, 1970: 74).

For the other hand, the Mawāli's first large-scale entry into the Islamic field was in the form of an army of four thousand men. After the defeat of Rostam Farrokhzad, the commander of the Iranian corps against the Muslims, and his death, mawāli decided to convert to Islam. To this end, they entered into negotiations with Sa'd ibn Abi Waqqas, the commander of the Muslims (Momtahen, 2006). Mawāli were known at that time as the emperor's soldiers and gave their leadership to a person named 'Deylam'. After entering the Islamic field, they made a pact with a tribe of Bani Tamim led by Zohra ibn Hawiyah and thus became known as Mawāli Bani Tamim. After fighting in the battle of Mada'in, they came to Kufa and settled in an area of it (Balazori, 1920). It was not obligatory for mawāli to stay with the tribe in the city where their master lived; that is, they were free to choose to live wherever they wanted, provided that there was no relationship such as serving or working for the master as a treasurer or lawyer, etc. that would require them to stay with him (Momtahen, 2006).

\section{Mawāli's bottlenecks in different periods}

The Arabs took wives from mawāli but did not allow them to marry Arab women. These discriminations against mawāli intensified during the Umayyad domination over the Islamic government so that they were called elj (meaning fat wild ass) and were never called with a

respectable nickname (Zaydan, 1986). Mawāli were not allowed to pray over their dead people and at the time of eating a meal, they were placed aside so that their being mawāli would become 
evident. "In the courts, their testimony was not accepted and in wars, they were not given the position of a commander or other important positions and even were not allowed to ride horses and were used as people dying in place of others and as regular infantry" (Zubaydi, 1970, p. 77). Even Hajjaj bin Yusuf, the ruler of Iraq in the days of the Umayyads, cauterized the hands of mawāli so that they were distinguished from other classes (Momtahen, 2006). Additionally, Hajjaj ibn Yusuf, after defeating Ibn Ash'ath, arrested those mawāli who were in his company and ordered to cauterize them and tattoo the name of the land to which they were exiled on their hands (Zaydan, 1986).

The Arabs usually entrusted less important jobs to mawāli. For example, the job of a judge was never delegated to one of mawāli because, according to the Arabs, noble people were worthy of such positions and those with honorable lineage should have this position. Based on the foregoing, it is concluded that mawāli were never equal to the Arabs in terms of social status (Momtahen, 2006). The Arabs believed that mawāli were not of the same status as they were for three reasons:

1) Mawāli's lineage

2) The appointment of mawāli to the jobs that were not respected in the view of the Arabs

3) Mawāli being born a slave, especially in the case of mawāli of Ataqa

Mawāli formed an important part of the army of Imam Hussein. But in the incident of Ashura, they did not play a significant role on both sides involved, i.e. the forces of Imam Hussein (AS) and Yazid's corps. Mawāli's most political appearance was in Mukhtar's corps, which took place in $66 \mathrm{AH}$ so that most of Mukhtar's corps against the Umayyads were mawāli (Dinouri, 2005). Mukhtar Thaqafi was considerd a Shiite figure and in Sunni historical books as well as books on sectarianism, various beliefs have been attributed to him and it has been stated that Mukhtar Thaqafi claimed the Mahdism of Muhammad ibn al-Hanafiyyah, the son of Ali, and considered himself as his representative in Kufa (Tabari, 1995). Mahdism ostensibly shares Shiite beliefs and was not widespread in Arab circles until then. Hence, it was thought that these beliefs were instilled in him by Mukhtar Thaqafi's Iranian troops. In this way, the great role of mawāli as one of the social strata that constituted the city of Kufa during this period is clarified. 


\section{Mawāli agreeing and cooperating with the Umayyads}

It should be noted that according to available resources, until the end of Mukhtar Thaqafi's uprising in $66 \mathrm{AH}$, religious, Shiite and ideological teachings were very rare among mawāli and religious beliefs such as Mahdism, Vesayat, Rij'at (return), Badā, infallibility, etc. were unknown to them (Tabari, 1995). Therefore, they could not have such cultural and ideological power to influence people like Mukhtar Thaqafi and the Kufi Arabs of Mukhtar's corps and as it was mentioned, "the only reason for them to join Mukhtar Thaqafi's corps was friendship with AhlulBayt and liberation from the oppression of the Umayyads and their agents, as well as liberation from social and economic discrimination and legal deprivation. Despite the prevalence of antiUmayyad tendencies in mawāli circles, many of them also started to cooperate with the Umayyad government and many of Ziyad ibn Abihi's guards were from mawāli. Further, according to some resources, the killer of Hani ibn Urwa was the servant of Ubayd Allah ibn Ziyad, who was known as Turkish Rashid and was considered one of mawāli (Tabari, 1995).

\section{The events of the Umayyad period in Kufa}

During the events of the Umayyad period in Kufa in the early first century and during the formation and ideological consolidation of Shi'ism, which usually included the period from the time of Imam Sajjad to Imam Sadiq, the non-Arab companions of these great men and Imams, who were referred to as mawāli, constituted a negligible percentage compared to the Arab companions of those great men so that out of 61 companions of Imam Sajjad, only 20 were mawāli and also, out of 466 companions of Imam Baqir, 25 were mawāli and only 440 out of 3223 companions of Imam Sadiq were mawāli (Ja'farian, 2003). In the Umayyad period, in spite of the strictness and wrongdoings and discrimination against mawāli and the Arabs' prejudice and with respect to the Umayyad's idea of tribalism, which had prevented mawāli from doing any activity, important figures appeared among them in various fields, like Sa'id ibn Jubayr (94 AH), Tawus ibn Sian (16 AH), Abdul Hamid Katib (132 AH), and Nafi' Deylami (117 AH) (Hamavi, 1979).

Many of the important heads of the administrative organization as well as a number of Umayyad secretaries, advisers, employees, and government officials were non-Arabs, despite their harsh and discriminatory policies toward the mawāli and the reason was the Arab belief indicating that Arabs have been created for mastery and lordship and others for slavery and servitude. Therefore, some jobs, especially industry and agriculture, trade and cultivation, and some court 
affairs were entrusted to mawālia and they were just rulers and engaged in political affairs, and considered accounting, bookkeeping, and correspondence as low-ranking jobs, and appointed mawāli to them" (Jurji Zaydan, 1986: 699). But it should be noted that this was not only due to this Arab belief, but the Arab people were farther away from industry than any other nation or ethnic group.

According to the writings by Ya'qubi, a number of mawāli revolted in Kufa during Muawiyah's rule against his governor, Mughira ibn Shu'ba. They were under the command of a man named Abu Ali. Although they had converted to Islam, they did not surrender to Muawiyah and said that they would never become polytheists and it did not take long that all were killed in a clash in "Badoria" region (Ya'qubi, 1992).

\section{The role of mawāli of Kufa in the uprising of Mukhtar Thaqafi}

In his uprising, Mukhtar Thaqafi, instead of the extensive use of Arab tribes and aristocrats in Kufa, focused all his efforts on using the power of mawāli who were humiliated throughout the years of the Umayyad rule because of the Arab ethnic tendencies promoted by the supporters of the Umayyads. During all these years, this social stratum suffered the worst disrespects and injustices and was deprived of special social positions. Mukhtar's strength was the use of this humiliated force (Ya'qubi, 2002).

In addition to the support of the people of Kufa and Tawwabin (the penitents), Mukhtar also gained the support of mawāli who were in fact among the weak and oppressed because he pledged allegiance to the people to follow the Quran and the Sunnah (tradition) of the Prophet and the vengeance for the killing of Hussein ibn Ali (AS) and to defend the weak and the oppressed (Zarrinkoub, 2000). When a number of people came to Mukhtar Thaqafi to verify his claim as being approved by Muhammad ibn al-Hanafiyyah, he said: "Regarding what you said that someone invited you to avenge the blood of Ahlul-Bayt, I swear by God that I want God to take revenge for us at the hands of whomever He wants from His servants (Balazori, 1987).

Since Kufa was the center of the Iraqi Shiites and the aristocrats of Kufa were opposed to Mukhtar, he tried to use the power of the people of Kufa, including those who did not participate in Tawwabin uprising or returned from it, for the benefit of himself and Ahlul-Bayt (AS) and against the aristocrats of Kufa (Ibn Athir, 1992; Tabari, 1995). 
The suppression of the aristocrats of Kufa and Mukhtar's search for the killers of Imam Hussein (AS) caused the aristocrats to flee and meanwhile, the aristocrats of Kufa and Zubayrian allied to fight Mukhtar" (Dinouri, 2005). Eventually, Mukhtar's excessive attention to and trust in mawāli and non-Arab people caused most individuals to consider his movement as an anti-Arab movement and as a result, they joined Mus'ab ibn Zubayr, Mukhtar's enemy and stubborn opponent, preparing the ground for his defeat" (Momtahen, 2006).

The situation in Kufa changed during Mukhtar's time. Slaves would kill or even sometimes abuse their masters if they had a role in Karbala to the extent that they made their master give a piggyback. The aristocrats and oppressors were humiliated. On the other hand, Mukhtar had killed many people. Zubayr's sons as well as the Umayyads and the fugitive aristocrats of Kufa became his enemies. For this reason, they launched the most severe propaganda attacks on him. They said that he claimed to be a prophet and that he was a liar and power seeker, and in short, they attributed any irrelevant word they could to him (Ja'farian, 2003).

\section{The role of mawāli of Kufa during the time of Imam Baqir and Imam Sadiq}

In the history of Islam, the greatest changes and transformations occurred during the period of Imamate (leadership) of Imam Hassan (AS), which was contemporary with the Umayyad caliphate. "The Umayyads tarnished the image of religion and confused Muslims by turning the caliphate into a monarchy, distorting the teachings of Islam, spreading ideas mixed with Arab racial prejudice and fabricating hadiths and superstitions" (Pishvaei, 2002). In this situation, "the presence of Shiite Imams and especially Imam Baqir (AS) played an important role in the purification and reconstruction of religious culture and provided the ground for the establishment of Shiite jurisprudence or Ja'fari jurisprudence by his dear son, Imam Sadiq (AS)" (Ja'farian, 2003).

The life of Imam Baqir (AS) coincided with the Umayyad caliphate and during this period, the Shiites were severely persecuted. This strictness began from the very beginning of the Umayyad caliphate, but intensified in some periods. "For example, during the twenty-year rule of Hajjaj ibn Yusuf in Iraq, the Shiites were subjected to the worst pressure. Hajjaj was one of the cruel and oppressive commanders of the Umayyads who played a significant role in strengthening the Umayyad caliphate since Abdul Malik ibn Marwan came to power. Abdul Malik, due to the devotion of Hajjaj towards the Umayyads, gave him the government of Iraq since 75. His reign 
was one of the bloodiest periods of the Umayyad caliphate and during this period, Hajjaj were very strict with the Shiites, Kharijites and Iranians. Hajjaj ordered contrary to Islam that non-Arab Muslims, like infidels, must pay Jizyah (tribute)" (Kheiri, 1983: 134).

What happened after the painful incident of Karbala in $61 \mathrm{AH}$ was the disruption of composition and serious transformation among the social classes of revolutionaries and also those who supported the revolutionaries but were not very serious in the struggle despite their hatred of the Umayyad regime, due to not having a clear stance. The revolutionaries tried more than ever to remove the main obstacle, i.e. the social stratum of the aristocracy, and isolate the aristocrats before facing the enemy and not to rely on their verbal support and empty slogans in the confrontation (Beizoun, 1941).

Kufa was the place of publication and development of Islamic sciences from the beginning of its establishment. Massignon writes in his book Khitat al-Kufa: Some civilized and urban tribes from Yemen and Hadhramaut, such as the tribes of Kanda, Bajila from Yemen, Mazhaj, Hamir, Hamedan and the tribe of Bani Abdul Qays from the city of Hijr and the tribe of Bani al-Hamra from Iranians, founded the scientific and intellectual movement of Kufa (Kheiri, 1983).

The life periods of each of the Imams had special features according to the conditions of the time and therefore, each can be used in a specific field. The era of Imam Sadiq (AS) can be considered the period of Cultural Revolution in the history of the lives of religious leaders and imams; an era that, on the one hand, due to the development of the geographical extent of the Islamic world and the entry of schools of thought outside the religion of Islam in the scope and territory of Islamic rule, had caused the conflict of opinions and clashes of ideas to reach its peak and this drew Muslims into challenging ideological debates. On the other hand, this conflict of opinions and clashes of ideas had led to the emergence of different sects and religions within the Islamic society, each promoting its own ideas and beliefs. The fact that Muslims were faced with different schools and ideas had created special conditions for the Islamic society (Hassan, 1977).

\section{Mawäli's role in the fall of the Umayyad dynasty}

Explicit Arabism prevailed in the Umayyad government. Non-Arabs who converted to Islam for various motives were deprived of many important privileges and still had to pay Jizyah even though they became Muslim. The Umayyads themselves were from Quraysh and Qays tribes and were not accustomed to the anti-racist teachings of Islam. On the other hand, they did not 
understand the expansion of the geographical scope of Islam. So, the most natural result was the mawāli's movement, which also played a role in the fall of the Umayyad Caliphate (Zaydan, 1986). The spread of Islam in the Central Asia and the gradual decrease in the collection of Jizyah due to the conversion of the people of this region to Islam caused the emptying of the treasury. Therefore, the policy of collecting Jizyah from new Muslims was resumed. Farmers had to pay tribute instead of tithes. This led to a revision of previous policies and property (ownership) became free for all Muslims. But mawāli did not give up his alliance with the Abbasids. In general, the phenomenon of economic discrimination was another factor in the fall of the Umayyads (Ja'farian, 2003).

Socially, by getting rid of the hard life of the past after the conquest of Islam and growing up in the Islamic culture, the mawāli believed that they were no less in the field of science than the Arabs. This new class later became the leader of the Abbasid dynasty during the caliphate. The weakness of the Arab element due to the rivalry between the Qaysi and Yemeni branches in Khorasan led to the emergence of Iranian forces, which played a key role in the victory of the Abbasids and the destruction of the Umayyads (Athir, 1992).

Internal conflicts weakened the Umayyads day by day and thus prepared a good opportunity for the protesting people to the point that they made the Umayyad rulers faced with a serious threat by their successive uprisings and revolts. For example, with the death of Yazid, the people of Medina in the battle of Harra, Tawwabin and Mukhtar in Iraq and the Zubayrian in Mecca waged great wars against the Umayyad caliphs. In the last years, the Alawites and Abbasids revolted until the last Umayyad caliph (Marwan ibn Muhammad known as Marwan Hamar) was killed by the Abbasids, and with his assassination, the Umayyad rule officially ended (Pishvaei, 2002).

\section{Conclusion}

Kufa was the most important Islamic city in the first centuries, and the influence of classes on its political developments was very significant. In the time of Uthman, the Arabs considered mawāli as second-class citizens and not only had they promoted this way of thinking that the Arabs have conquered them, but also they treated them from a position of racial superiority. This led to discontent among the mawāli of Kufa. Uthman's policy of discrimination included not only nonArabs but also the superiority of the Umayyads over other Arabs, especially the Yemeni Arabs. This led to the formation of a strong front of the Iranians and Yemenis of this city against him. In 
addition, Muawiyah was concerned about the large population of Iranians living in Kufa so that at his command, Ziyad ibn Abihi relocated many of them to Levant, Basra and Khorasan. This issue can be considered as one of the main factors in the spread of Shi' ism in this region. Arabism that began since the time of Umar ibn al-Khattab, considering mawāli as second-class citizens and depriving them of the spoils of war and inequality in the distribution of the treasury, which intensified during the time of the later caliphs, especially the Umayyad period, made a huge group of mawāli of Kufa, at least intellectually, associated with these currents.

During the Umayyad rule, mawāli were never called with a respectable nickname. They were not allowed to pray over their dead people and ride horses and were used as infantry. During their hard life in Kufa, they did not forget the taste of Alawite justice and since the martyrdom of that Imam; their trace can be seen in most of the anti-Umayyad and Abbasid revolts. The intensity of Iranians' anger over this discrimination led them to join any movement (including the Kharijites) that chanted the slogan of equality and justice, though falsely. The culmination of this anger and discontent can be seen in the joining of nearly twenty thousand Iranians to Mukhtar's uprising, whose main slogan was revenge for the blood of Hussein ibn Ali (AS) and its approach was equality of Arabs with non-Arabs. The uprising of the Iranians of Mukhtar's corps in $66 \mathrm{AH}$ can be considered as the first uprising of the Iranian Shiites after the emergence of Islam, which became the basis for the influence of Zaydi Shi'ism in Tabarestan and Alawites' turning to that land.

\section{References}

Aynehvand, S. (2008). A series of Shia uprisings. Tehran: Research Institute of Humanities publisher. http://ketab.ir/Publisherview.aspx?Publisherid=6887

Balazori, A. (1920). Ansab al-Ashraf (Genealogies of the Nobles). Beirut: Scientific Corporation Publications. https://www.masharegh.com/

Balazori, A. (1987). Futūḥ al-Buldān. Translated by Dr. Mohammad Tavakkol, Negar Publisher. http://naghshonegar.org/

Beizoun, I. (1941). Al-Tawwabun. Institute for Research and Publication of the Knowledge of Ahlul-Bayt. http://ahlolbait.com/ 
Buraq Najafi, H. (2002). History of Kufa. Translated by Saeid Rad Rahimi, First Edition, Mashhad: Astan Quds Razavi Publications. https://behnashr.razavi.ir/

Dehkhoda, A. A. (1998). Dehkhoda Dictionary. Second Edition, Tehran: University of Tehran Press. https://press.ut.ac.ir/

Dinouri, A. (1991). Al-Akhbar al-Tuwal. Qom: Sharif Razi Publications. https://www.manoketab.com/

Dinouri, A. (2005). Imam and politics. Translated by Seyyed Nasser Tabatabaei, Tehran: Qoqnus Publications. https://qoqnoos.ir/Fa/

Ibn A'tham Kufi, M. (1993). Al-Futuh. Old Persian translation by Ahmad Mostofi Heravi, edited by Gholam Reza Tabatabaei Majd, Tehran: Islamic Revolution Publications and Education. http://mtif.org/organ/

Ibn Athir, A. (1992). Al-Kamil. Translated by Abbas Khalili, Tehran: Elmi Publications. http://elmipublications.com/

Ibn Sa'd, M. (1989). Al-Tabaqat al-Kubra (Book of the Major Classes). Edited by Mohammad Abdul Qadir Ataa, Beirut: Dar al-Kutub al-Ilmiyah Publications. https://www.masharegh.com/

Istakhri, I. (1989). Masālik wa Mamālik (The Book of Roads and Kingdoms). With the effort of Iraj Afshar, Third Edition, Tehran: Scientific and Cultural Publication. https://elmifarhangi.com/

Izadi, H. (2000). Historical Geography of Kufa. History of Islam, Baqir al-Olum University Publications, Vol. 4. http://www.bou.ac.ir/portal/

Ja'fari, H. M. (2005). Shi'ism in the path of history. Translated by Seyyed Mohammad Taqi Ayatollahi, Third Edition, Tehran: Farhang Publications. https://ketabkhaneh-farhang.ir/

Ja'farian, R. (2003). Political history of Islam. Qom: Tarikh Publications. https://qoqnoos.ir/Fa

Kheiri, M. (1983) Islam in fourteen centuries. Third Edition, Tehran: Nashr-e Eslam Publications. http://www.nashreislam.com/

Le Strange, G. (2004). Historical geography of the lands of the Eastern Caliphate. Translated by Mahmoud Erfan, Sixth Edition, Tehran: Scientific and Cultural Publications. https://elmifarhangi.com/

Mahallati, R. (2004). Summary of the History of Islam. Sixth Edition, Tehran: Publisher of Islamic Culture. https://daftarnashr.org/ 
Majlesi, M. B. (2009). Bihar al-Anwar (Seas of Lights). Second Edition, Tehran: Maktab-e Eslami Publications. https://hawzah.net/fa

Momtahen, H. A. (2006). Shu'ubiyya movement. Tehran: Scientific and Cultural Publications. https://elmifarhangi.com/

Noss, J. (1991). Man's religions. Translated by Ali Asghar Hekmat, Tehran: Islamic Revolution Publications and Education. http://mtif.ir/organ/48345

Pishvaei, M. (2002). Sireye Pishvayan (manner of the leaders). 13th Edition, Qom: Imam Sadiq Publishing Institute. http://ketabesadiq.ir/

Shahrokhi, A. (2009). Islamic History and Culture: The role of Iranians of Kufa in Mukhtar's movement. $\quad$ Meshkat $\quad$ Publications, $\quad$ No. 100. https://www.ketabcity.com/BookList.aspx?Type=PubRefid $\&$ Code=59544

Shahrokhi, A. (2010). An inquiry into the role of the Iranian Shiites of Kufa during the first century AH. Quarterly Journal of History, 5(17), 45-53. https://www.magiran.com/paper/1980522 Tabari, M. (1993). Tārīkh al-Rusul wa al-Mulūk (The History of the Prophets and Kings). Translated by Abul Qasem Payande, Fourth Edition, Asatir Publications.

Tabari, M. (1995). Tarikh al-Tabari (The History of al-Tabari). translated by Abul Qasem Payande, Fourth Edition, Tehran: Asatir Publications. https://www.adinehbook.com/gp

Tabari, M. (n.d). Tārīkh al-Rusul wa al-Mulūk (The History of the Prophets and Kings). Cairo: Matba'at al-Huseiniyah al-Misriyah publisher. https://www.adinehbook.com/gp

Vosouqi, M. \& Nik Kholq, A. A. (1992). Fundamentals of Sociology. Fifth Edition, Tehran: Kheradmand Publications. https://www.ketabcity.com/BookList.aspx?Type=PubRefid\&Code=3519

Ya'qubi, A. (1960). Tarikh al-Ya'qubi (History of Ya'qubi). Beirut: Dar Sader Publications. http://www.imam-khomeini.ir/fa

Ya'qubi, A. (1992). Tarikh al-Ya'qubi (History of Ya'qubi). Translated by Muhammad Ibrahim Ayati, Fourth Edition, Tehran: Scientific and Cultural Publications. https://elmifarhangi.com/

Ya'qubi, A. (Ibn Wadhih). (2002). Al- Buldān. Translated by Muhammad Ibrahim Ayati, Fourth Edition, Tehran: Scientific and Cultural Publications. https://elmifarhangi.com/ Yaqut Hamawi, Sh. (1979). Mu'jam al-Buldān. Beirut: Dar Ihya al-Turath al-Arabi Publications. 
Zarrinkoub, M H. (2000). History of Iran after Islam. 8th Edition, Tehran: Amirkabir Publications. http://amirkabirpub.ir/

Zaydan, J. (1986). History of Islamic Civilization. Translated by Jawahir Kalam; Tehran: Amirkabir Publications. http://amirkabirpub.ir/

Zubaydi, M. H. (1970). Social and economic life in Kufa. Cairo: National publisher in Egyptian. https://www.gisoom.com/book/137223 